\title{
Short-term responses of mammalian carnivores to a sudden collapse of rabbits in Mediterranean Spain
}

\author{
Pablo Ferreras $^{\mathrm{a}, *}$, Alejandro Travaini ${ }^{\mathrm{b}}$, S. Cristina Zapata ${ }^{\mathrm{b}}$, Miguel Delibes ${ }^{\mathrm{c}}$ \\ a Instituto de Investigación en Recursos Cinegéticos (IREC), CSIC-UCLM-JCCM, Ronda de Toledo s/n, 13005 Ciudad Real, Spain \\ ${ }^{\mathrm{b}}$ Centro de Investigaciones Puerto Deseado, UNPA-CONICET, CC 238. 9050 Puerto Deseado, Santa Cruz, Argentina \\ ${ }^{\mathrm{C}}$ Dept. Conservation Biology, Estación Biológica de Doñana, CSIC, Américo Vespucio s/n, 41092 Sevilla, Spain
}

\begin{abstract}
The European rabbit (Oryctolagus cuniculus) is a key prey species for most Mediterranean predators in the Iberian Peninsula, including some endangered species such as the Iberian lynx (Lynx pardinus). Rabbit populations in the Iberian Peninsula have collapsed since the arrival of rabbit haemorrhagic disease (RHD) in the late 1980s. We studied the dietary and numerical responses of five species of mammalian carnivores to this decline in the Doñana National Park (south-west Spain), where RHD arrived in 1990. Behavioural responses of the Iberian lynx, a rabbit specialist, were also studied through radio-tracking. All carnivores reduced rabbit intake with decreasing rabbit densities immediately after the initial RHD outbreak, though the level of reduction varied among species. Reductions in rabbit consumption were highest for the Eurasian badger (Meles meles) and the red fox (Vulpes vulpes), low for the genet (Genetta genetta) and mongoose (Herpestes ichneumon), and negligible for the Iberian lynx, thus confirming its strong dependence on rabbits for survival. The Iberian lynx social system was temporarily altered. Female lynxes increased their home range size and no subadult lynxes dispersed in the year following the rabbit crash, causing a temporal local increase of lynx density, which returned to previous values a year after the arrival of RHD. The red fox showed a negative numerical response, reducing its abundance following the rabbit decline. Despite the fact that rabbit consumption was reduced in most carnivores, the role of joint predation is discussed as a factor in the failure of rabbit recovery after this new disease.
\end{abstract}

\section{Zusammenfassung}

Das europäische Kaninchen (Oryctolagus cuniculus) ist eine der Schlüsselbeutearten für die meisten mediterranen Prädatoren auf der iberischen Halbinsel einschließlich einiger gefährdeter Arten wie z.B. dem iberischen Luchs (Lynx pardinus). Die Kaninchenpopulationen auf der iberischen Halbinsel sind seit der Ankunft der Chinaseuche (RHD) in den späten 1980er Jahren zusammengebrochen. Wir untersuchten die Reaktionen von fünf Raubsäugern auf diese Abnahme im Dõnana Nationalpark (Südwest Spanien), wo RHD 1990 auftrat, in Bezug auf die Nahrungszusammensetzung und Anzahl. Die Reaktionen in Bezug auf das Verhalten wurden beim iberischen Luchs, einem Kaninchenspezialisten, durch Radiotelemetrie untersucht.

\footnotetext{
${ }^{*}$ Corresponding author. Tel.: +34 926295450; fax: +34 926295451.
}

E-mail address: pablo.ferreras@uclm.es (P. Ferreras). 

Alle Carnivoren reduzierten die Kaninchenaufnahme mit sinkenden Kaninchendichten direkt nach dem ersten Ausbruch von RHD, obwohl das Ausmaß der Reduktion zwischen den Arten variierte. Die Reduktionen in der Kaninchenaufnahme waren beim europäischen Dachs (Meles meles) und beim Rotfuchs (Vulpes vulpes) am höchsten, gering bei der Ginsterkatze (Genetta genetta) und der Manguste (Herpestes ichneumon) und vernachlässigbar beim iberischen Luchs und bestätigte dadurch dessen starke Abhängigkeit von den Kaninchen für das Überleben. Das Sozialsystem des iberischen Luchses war zeitweise verändert. Weibliche Luchse vergrößerten die Größe ihrer Reviere, und es gab keine Ausbreitung durch subadulte Luchse in dem Jahr, das dem Kaninchenzusammenbruch folgte, wodurch eine temporäre, lokale Erhöhung der Luchsdichten verursacht wurde, die ein Jahr nach der Ankunft der RHD zu den Werten des vorhergehenden Jahres zurückkehrten. Der Rotfuchs zeigte eine negative numerische Reaktion und die Abundanz war in Folge des Kaninchenzusammenbruchs verringert. Obwohl die Kaninchenaufnahme bei den meisten Carnivoren reduziert war, wird die Rolle der gemeinsamen Prädation als ein Faktor diskutiert, der die ausbleibende Erholung der Kaninchen nach dieser neuen Krankheit erklärt.

(C) 2011 Gesellschaft für Ökologie. Published by Elsevier GmbH. All rights reserved.

Keywords: Functional responses; Numerical responses; Rabbit haemorrhagic disease; Diet changes; Iberian lynx; Prey changes

\section{Introduction}

Predators can respond to changes in prey density either functionally, through changes in behaviour, diet and predation rates, or numerically, through changes in population size (Ward \& Krebs 1985; O’Donoghue, Boutin, Krebs, \& Hofer 1997). According to their use of prey resources, predators have been classified as specialists or generalists (Newton 1998). Following optimal foraging theory, specialist predators use key resources independent of its availability, whereas generalists change prey foraging patterns according to their availability (Futuyma \& Moreno 1988). Theory predicts that specialists would respond numerically to deplete prey, whereas generalists may respond functionally as well as numerically (Andersson \& Erlinge 1977). Other common functional behavioural responses are changes in predator home range size (Fuller 1989), as well as changes in the number of transient and dispersing individuals (Ward \& Krebs 1985).

The European rabbit (Oryctolagus cuniculus) is a key prey for the Iberian vertebrate predator assemblage (DelibesMateos, Delibes, Ferreras, \& Villafuerte 2008). Several threatened species such as the imperial eagle (Aquila adalberti) and the Iberian lynx (Lynx pardinus) are highly dependent on rabbit availability (Ferrer \& Negro 2004). In Spain, rabbit haemorrhagic disease (RHD) first appeared in the wild in 1988, and five years later it had spread all over the country, causing high rabbit mortality (Villafuerte, Calvete, Blanco, \& Lucientes 1995). Most rabbit populations have not recovered to previous levels (Delibes-Mateos, Ferreras, \& Villafuerte 2009). Responses of predators to the rabbit decline after RHD include a reduction in litter size of the red fox (Vulpes vulpes, Villafuerte, Luco, Gortázar, \& Blanco 1996), and a decrease in reproduction in golden eagles (Aquila chrysaëtos L., Fernández 1993) and eagle owls (Bubo bubo, Martínez and Zuberogoitia 2001).

In this study, we analysed short-term responses of five carnivore species from Doñana National Park to the substantial rabbit decline following the initial RHD outbreak. Previous to the RHD arrival, the Iberian lynx was described as a rabbit specialist predator (Delibes 1980; Palomares, Delibes, Revilla, Calzada, \& Fedriani 2001), whereas the genet (Genetta genetta) was described as a mice specialist (Palomares \& Delibes 1991). The other predator species (red fox, Eurasian badger Meles meles, and Egyptian mongoose Herpestes ichneumon) were considered before RHD as generalists, preying heavily on rabbits whenever these are at high densities (Rau 1987; Palomares 1993; Martín, Rodríguez, \& Delibes 1995). We predict that the strong decline of rabbits would affect mostly the numbers of the Iberian lynx, as well as its spatial behaviour, particularly it should induce an increase in home range size and overlap. The mice specialist, the genet, should not be affected by the rabbit decline, whereas the generalist carnivores would change their diet, increasing their trophic diversity. Changes in generalist predator populations would be expected only in those for which rabbits represent a key resource.

Since the rabbit decline induced by RHD is widespread throughout the Iberian peninsula, our results can serve as a guide to the consequences for the whole Iberian carnivore assemblage. Our results are relevant for the conservation of the Iberian lynx, since they can test its ability to temporarily consume alternative prey when rabbits are scarce. We will also discuss the potential effects on the lack of rabbit recovery of the observed responses of carnivores.

\section{Materials and methods}

\section{Study area}

The study was carried out in the Doñana Biological Reserve (6794 ha), core area of Doñana National Park (DNP, SW Spain, $37^{\circ} \mathrm{N}, 6^{\circ} 30^{t} \mathrm{~W}$ ). It is occupied mainly by Mediterranean scrubland and the ecotone between scrubland and marshland, where high rabbit densities and a high diversity of vertebrate predators are found. The climate is Mediterranean subhumid, with hot, dry summers and mild, rainy winters (500 mm per year). 
The RHD epizootic wave reached the study area in March 1990 (Villafuerte, Calvete, Gortázar, \& Moreno 1994). As a result, Doñana rabbit populations have collapsed by the end of 1990 and they have remained below $10 \%$ of those numbers before the arrival of RHD (Moreno et al. 2007).

Doñana harbours one of the most diverse communities of vertebrate predators within the Iberian Peninsula, most of them preying upon rabbits. Density values of the different carnivore species are known from field studies carried out before the RHD arrival. The red fox was the most abundant carnivore species (1.37-1.7 ind./km²; Rau 1987) and the Iberian lynx $\left(0.1-0.28\right.$ ind. $/ \mathrm{km}^{2}$; Ferreras 1994) the least abundant species. Badger densities were estimated as $0.23-0.28$ ind. $/ \mathrm{km}^{2}$ (Revilla, Delibes, \& Travaini 1999), mongoose as 2 ind. $/ \mathrm{km}^{2}$ (Palomares \& Delibes 1992) and genet as 0.67 ind. $/ \mathrm{km}^{2}$ (Palomares \& Delibes 1994).

\section{Diet analysis and comparison with data before RHD}

Carnivore diets after the rabbit population crash were estimated from fresh scats collected between May 1990 and January 1992. For this purpose, an experienced technician walked across the study area searching for fresh scats on several days each month. The predator producing each scat was identified by its size, shape and the specific deposition pattern. The long experience of the field collector makes us confident about the correct species assignment, although molecular techniques were not available at the time of field work. Mammalian prey were identified by their hair and tooth characteristics and grouped for presentation into rabbits, ungulates and small mammals. The remaining food items were grouped into wider categories: birds, fruits, amphibians, reptiles, eggs, crayfish and insects.

The importance of rabbits in the diet was expressed using the frequency of occurrence and the percentage of ingested biomass, estimated from the dry weight of rabbit remains and correction factors (Palomares \& Delibes 1990 for mongooses and genets; Martín et al. 1995 for badgers; Aldama 1993 for lynx; Lockie 1959 for foxes).

Carnivore diets before the rabbit crash were obtained from studies carried out in the same area between 1973 and 1986, that is, before the arrival of RHD (Delibes 1980; Palomares \& Delibes 1991; Martín et al. 1995). Rabbit density during that time ranged between 2.2 and 8.5 rabbits/ha (Moreno et al. 2007).

We tested for differences in the proportion of scats containing rabbit remains before and after the arrival of RHD using chi-square tests. Diet diversity was quantified with the Levins diversity index (Levins 1968) using the estimated ingested biomass of food categories. Pianka's (1973) symmetrical overlap index was employed to estimate the similarity of diet composition before and after RHD for each carnivore species and the trophic overlap between pairs of carnivores, using in both cases the estimated ingested biomass for all food categories.

\section{Changes in the abundance of carnivores}

Carnivore numerical responses to the rabbit decline were evaluated through track counts in the Doñana sandy soil. Eight $1.6 \mathrm{~km}$ permanent transects were evenly distributed along dirt roads in spring 1990, separated by at least $2 \mathrm{~km}$, and surveyed over the next six years (1990-1995). Two surveys were performed per year, just after the first rains (autumn) and at the end of the rainy season (spring). Each survey consisted of three consecutive days counting the tracks produced during the previous $24 \mathrm{~h}$. This method was useful for detecting tracks of the Iberian lynx, red fox, Eurasian badger and Egyptian mongoose. Common genets were mostly arboreal so their tracks were seldom detected, and therefore not included in the analyses. We used Generalized Linear Models to test for possible trends over years of the tracks recorded per $\mathrm{km}$ of dirt road and day, controlling for the effect of season and with transect as the sampling unit. All statistical analyses were performed with SPSS v. 11.5 (SPSS-Inc. 2002).

\section{Space use by the Iberian lynx}

The responses of the Iberian lynx were also studied using data from lynxes radio-tracked from one year before to one year after the arrival of RHD (1989-1991). Lynxes were radio-tracked following conventional procedures (Ferreras, Beltrán, Aldama, \& Delibes 1997). Seasonal home ranges were estimated using the minimum convex polygon, which excludes the 5\% most external fixes (95\% MCP), using the program RANGES V (Kenward \& Hodder 1996). Only individuals with a minimum of 30 independent locations for a given season were included in the analyses (Ferreras et al. 1997). We considered 3 seasonal intervals: spring (March-June), summer (July-October) and autumn-winter (November-February). The effect of sex and the temporal trends of seasonal home range size were analysed by Generalized Linear Models with the SPSS program (SPSS-Inc. 2002). Lynx minimum density was estimated following the method proposed by Mclellan (1988).

\section{Results}

\section{Dietary responses}

Rabbit occurrence in scats decreased after the RHD outbreak for all carnivore species. The decrease was largest for badgers (from $63 \%$ to $10.6 \%, P<0.001$ ) and foxes (from $31.4 \%$ to $9.9 \%, P<0.001)$, lower for genets and mongooses, and negligible for lynxes (Table 1).

The decrease in rabbit consumed biomass was largest for badgers (from $71.8 \%$ to $26.2 \%$ ) and it was also large for foxes (from $20.2 \%$ to $9.8 \%$ ), but it was of little magnitude in the other species (Table 2). The diets of the rabbit specialist (lynx) and the mice specialist (genet) were least affected by 
Table 1. Dietary responses of Doñana carnivores to the decline of rabbits after the arrival of rabbit haemorrhagic disease (RHD). Proportion of scats containing rabbit remains in the samples before and after the rabbit reduction. Sample sizes (number of scats) are shown in parentheses.

\begin{tabular}{|c|c|c|c|c|}
\hline \multirow[t]{2}{*}{ Species } & Before RHD & After RHD & \multirow[t]{2}{*}{$\mathrm{Chi}^{2}{ }^{\mathrm{a}}$ (1 d.f.) } & \multirow[t]{2}{*}{$P$} \\
\hline & \%Scats with rabbit, $N$ & \%Scats with rabbit, $N$ & & \\
\hline Lynx pardinus & $88.9(1537)^{\mathrm{b}}$ & $85.0(153)^{\mathrm{c}}$ & 1.74 & 0.167 \\
\hline Meles meles & $63.0(265)^{\mathrm{d}}$ & $10.6(141)^{\mathrm{c}}$ & 99.99 & $<0.001$ \\
\hline Vulpes vulpes & $31.4(781)^{\mathrm{e}}$ & $9.9(172)^{c}$ & 31.57 & $<0.001$ \\
\hline Herpestes ichneumon & $22.2(252)^{f}$ & $15.4(104)^{\mathrm{c}}$ & 1.73 & 0.20 \\
\hline Genetta genetta & $11.4(246)^{f}$ & $5.9(170)^{\mathrm{c}}$ & 3.03 & 0.086 \\
\hline
\end{tabular}

${ }^{\mathrm{a}}$ Chi-square test with Yates correction for continuity.

${ }^{b}$ Data from: Delibes (1980).

${ }^{\mathrm{c}}$ Data from: this study.

${ }^{\mathrm{d}}$ Data from: Martín et al. (1995).

${ }^{\text {e }}$ Data from: Rau (1987).

${ }^{\mathrm{f}}$ Data from: Palomares and Delibes (1991).

Table 2. Dietary responses of the carnivores from Doñana to the decline of rabbits after the arrival of the RHD: rabbit and other food categories expressed as estimated consumed biomass (\%), diet diversity estimated as the Levins B diversity index, and diet similarity as Pianka's (1973) symmetrical overlap index. The estimated ingested biomass of rabbit is shown in bold, and the food categories increasing after the rabbit decline are shown in italics. Sources of data on carnivore diet before RHD are the same provided in Table 1.

\begin{tabular}{|c|c|c|c|c|c|c|c|c|c|c|}
\hline \multirow[t]{2}{*}{ Food category } & \multicolumn{2}{|c|}{ Lynx pardinus } & \multicolumn{2}{|c|}{ Meles meles } & \multicolumn{2}{|c|}{ Vulpes vulpes } & \multicolumn{2}{|c|}{ Herpestes ichneumon } & \multicolumn{2}{|c|}{ Genetta genetta } \\
\hline & Before & After & Before & After & Before & After & Before & After & Before & After \\
\hline Rabbit & 84.7 & 74.9 & 71.8 & 26.2 & 20.2 & 9.8 & 14.3 & 12.3 & 6.9 & 6.2 \\
\hline Birds & 9.1 & 16.2 & 0.9 & 9.7 & 2.2 & 23.0 & 16.7 & 8.8 & 12.0 & 15.1 \\
\hline Ungulates & 5.4 & 7.5 & 0.0 & 0.0 & 2.1 & 48.7 & 17.8 & 29.9 & 0.0 & 0.0 \\
\hline Small mammals & 0.8 & 1.4 & 0.9 & 6.4 & 1.3 & 5.2 & 18.4 & 23.5 & 74.3 & 57.4 \\
\hline Undet. mammals & 0.0 & 0.0 & 0.0 & 0.0 & 0.0 & 0.0 & 0.0 & 7.1 & 0.0 & 0.0 \\
\hline Insects & 0.0 & 0.0 & 16.6 & 42.4 & 52.6 & 3.1 & 3.7 & 10.3 & 1.5 & 5.1 \\
\hline Amphibians & 0.0 & 0.0 & 6.9 & 0.2 & 0.0 & 0.0 & 6.2 & 5.7 & 2.0 & 5.7 \\
\hline Fruits & 0.0 & 0.0 & 1.3 & 9.5 & 21.6 & 6.4 & 0.0 & 0.0 & 0.0 & 0.0 \\
\hline Reptiles & 0.0 & 0.0 & 0.9 & 0.1 & 0.0 & 0.1 & 19.4 & 1.8 & 2.9 & 4.5 \\
\hline Eggs & 0.0 & 0.0 & 0.7 & 0.4 & 0.0 & 1.1 & 1.8 & 0.0 & 0.3 & 0.6 \\
\hline Crayfish & 0.0 & 0.0 & 0.0 & 5.1 & 0.0 & 2.6 & 1.7 & 0.8 & 0.1 & 5.4 \\
\hline Diversity index & 1.372 & 1.686 & 1.824 & 3.690 & 2.738 & 3.244 & 6.356 & 5.354 & 1.746 & 2.725 \\
\hline Diet similarity & \multicolumn{2}{|c|}{0.994} & \multicolumn{2}{|c|}{0.675} & \multicolumn{2}{|c|}{0.196} & \multicolumn{2}{|c|}{0.786} & \multicolumn{2}{|c|}{0.978} \\
\hline
\end{tabular}

the rabbit decline (similarity between before and after RHD for each species, Pianka index: $O=0.994$ and 0.978 , respectively). The lynx based its diet on rabbits and the genet on small mammals before and after RHD (Table 2). The red fox was the carnivore that changed its diet most $(O=0.196)$.

Food diversity after RHD increased for the species considered, except for the mongoose. The largest increase in trophic diversity occurred in badgers and foxes, which almost doubled their niche breadth by replacing rabbits with several food items (Table 2). The mongoose consumed similar amounts of rabbits before and after RHD. Nevertheless, it was the only carnivore for which trophic diversity decreased, as it based its diet on small mammals and ungulate carrion ( $>50 \%$ biomass) after RHD.

Trophic overlap between the Iberian lynx and the other species decreased or remained close to the values estimated before RHD (Table 3). Diet overlap between most pairs of generalist species increased after the rabbit crash, though
Table 3. Overlap among the diets of five mammalian carnivore species from Doñana National Park, expressed as Pianka's (1973) index using the proportions of consumed biomass of each food category, before and after the arrival of RHD.

\begin{tabular}{lll}
\hline & Before RHD & After RHD \\
\hline L. pardinus $\times$ M. meles & 0.964 & 0.528 \\
L. pardinus $\times$ V. vulpes & 0.338 & 0.346 \\
L. pardinus $\times$ H. ichneumon & 0.435 & 0.344 \\
L. pardinus $\times$ G. genetta & 0.117 & 0.168 \\
M. meles $\times$ V. vulpes & 0.526 & 0.248 \\
M. meles $\times$ H. ichneumon & 0.402 & 0.563 \\
M. meles $\times$ G. genetta & 0.110 & 0.357 \\
V. vulpes $\times$ H. ichneumon & 0.243 & 0.721 \\
V. vulpes $\times G$. genetta & 0.075 & 0.222 \\
H. ichneumon $\times$ G. genetta & 0.580 & 0.722 \\
\hline
\end{tabular}


not significantly (Wilcoxon paired-sample test: $Z=1.153$, $P=0.249$, Table 3).

\section{Behavioural responses of Iberian lynx}

Home range size significantly increased between 1989 and 1991 for females $(F=10.848$, 8 d.f., $P=0.009)$ but not for males ( $F=0.232$, 6 d.f., $P=0.931$, Fig. 1$)$. We did not detect any lynx reproduction in the study area the year of RHD arrival (1990) and the year after, whereas between 1987 and 1989 a minimum of two litters were known to be born per year across the study area (Ferreras et al. 1997).

During 1990, none of the six radio-tracked subadult lynxes dispersed, whereas $3 / 6$ and 6/7 subadult lynxes dispersed in 1989 and 1991, respectively (Ferreras et al. 2004). As a consequence, an unusually high density of lynxes was observed during 1990 (Fig. 2).

\section{Numerical responses}

Red fox abundance index showed a decreasing, significant trend $(F=3.912,5$ d.f., $P=0.006)$ after the rabbit decline, while the other carnivores did not show any clear trend (Fig. 3). A significant seasonal effect was observed for the abundance index of mongooses $(F=12.877,1$ d.f., $P=0.008$ ), mostly attributable to the low detectability of

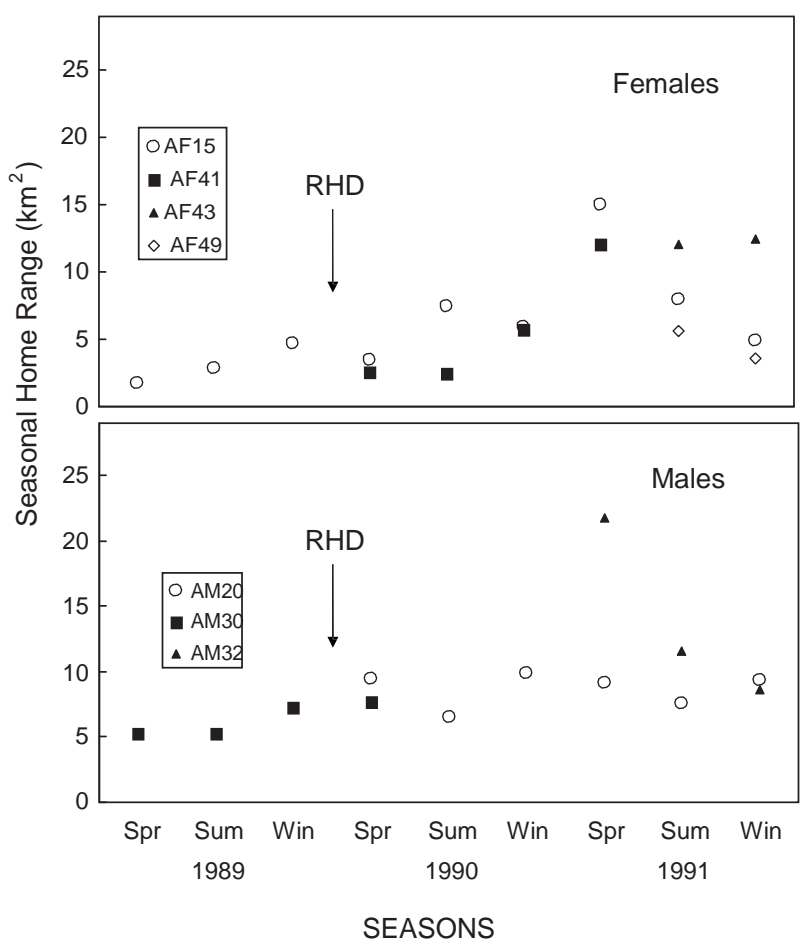

Fig. 1. Seasonal home ranges of adult Iberian lynxes expressed in $\mathrm{km}^{2}$ between one year before and two years after the arrival of rabbit haemorrhagic disease (RHD). Individuals are represented by different symbols. The arrow indicates the time of RHD arrival to rabbit populations in Doñana.

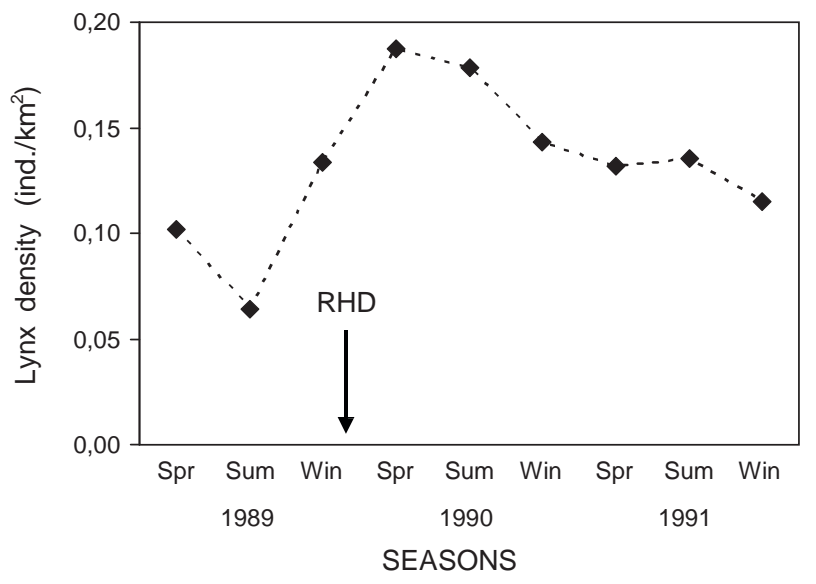

Fig. 2. Seasonal density of Iberian lynx (individuals per $\mathrm{km}^{2}$ ) in the study area before and during the rabbit decline. The arrow indicates the time when the rabbit haemorrhagic disease arrived to Doñana.

their small tracks in spring, when the sand on dirt roads was dry and loose.

\section{Discussion}

Our study can be considered as a "natural experiment", which tests some predictions as the outcome of an unreplicated, naturally occurring perturbation. Strong inferences about carnivore responses to rabbit reductions were, therefore, not possible. Nevertheless, our before-after approach allowed us to make valid causal inferences. Although observed changes in carnivore diets could be due to causes other than changes in rabbits, this is highly improbable considering the rabbit population collapse was the greatest change in prey availability during the study (Moreno et al. 2007).

\section{Dietary responses}

Lynx diet was still based on rabbits after the RHD outbreak, although the rabbit proportion was among the lowest ever reported (74.9\% of consumed biomass; Delibes 1980; Palomares et al. 2001; Gil-Sánchez, Ballesteros-Duperón, \& Bueno-Segura 2006). This confirms the Iberian lynx as an 'obligate' predator on rabbits. Its critical situation as an endangered species is likely related to its inability to "switch" prey (Ferreras, Rodríguez, Palomares, \& Delibes 2010). In contrast, the Canada lynx (Lynx canadensis), another specialized predator, can switch to alternative similar-sized prey during years of hare lows (O’Donoghue, Boutin, Krebs, Murray, \& Hofer 1998).

The diet of the common genet remained based on small mammals after RHD, in agreement with other studies (Palomares \& Delibes 1991; Virgós, Llorente, \& Cortes 1999). Its trophic diversity increase after RHD seems to be related mostly to an increase in the consumption of several 

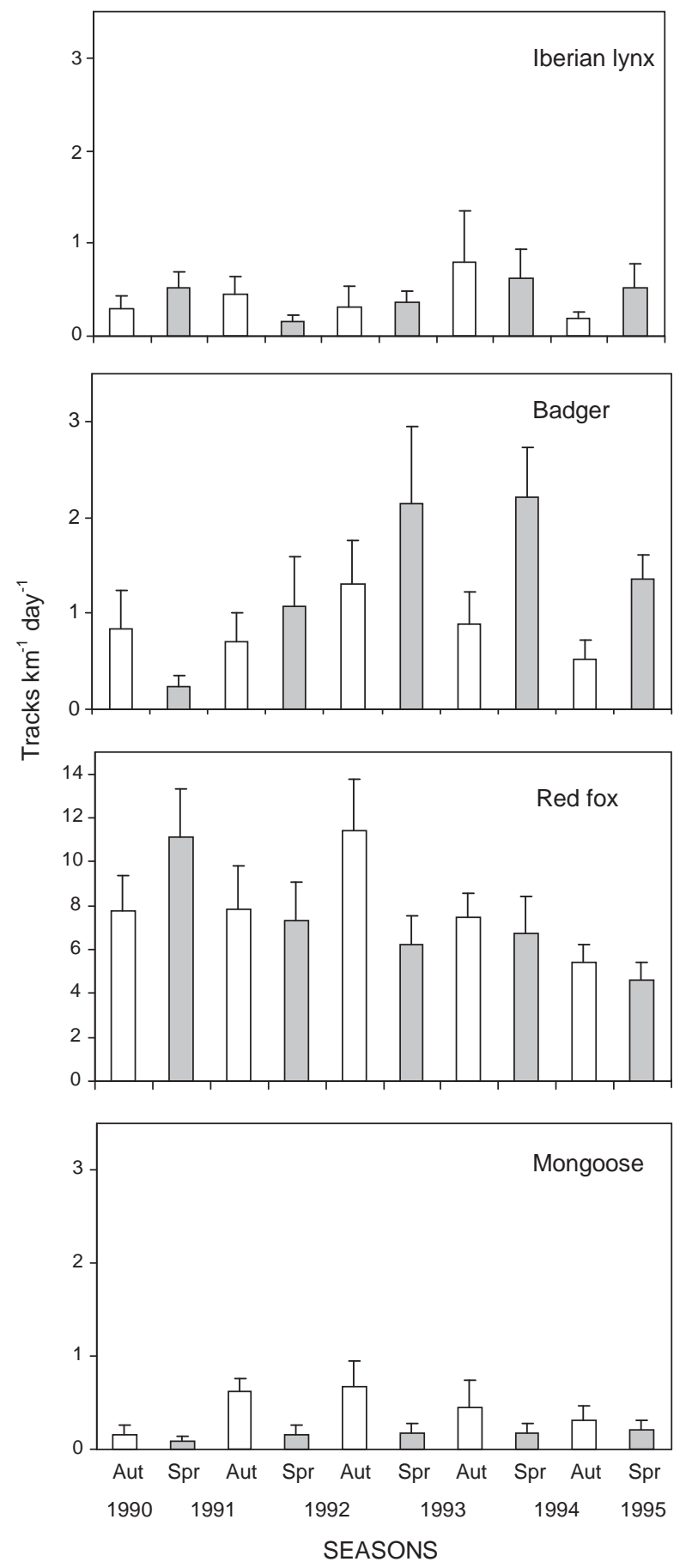

Fig. 3. Numerical responses to the rabbit decline of four species of carnivores (Iberian lynx, Eurasian badger, Red fox, and Egyptian mongoose), measured as changes in the index of abundance. The index employed is the mean (represented \pm standard error) number of tracks per $\mathrm{km}$ and day in eight $1.6 \mathrm{~km}$ long independent transects, counted during three consecutive days in autumn (Aut, white-shaded bars) and spring (Spr, grey-shaded bars) during six years after RHD arrival. prey, such as the American red swamp crayfish (Procamburus clarkii).

Rabbit intake decreased in all the remaining carnivores (Table 2). A case of "switching" occurred in the badger (Revilla \& Palomares 2002). The increase in the trophic diversity of fox and badger could also be related to the appearance of the American red swamp crayfish in trophic webs (Tablado, Tella, Sánchez-Zapata, \& Hiraldo 2010). The red fox behaves in Doñana as an opportunistic predator, preying upon rabbits when available (Delibes-Mateos, de Simón, Villafuerte, \& Ferreras 2008).

The increases in diet overlap among generalist species after the arrival of RHD supported our predictions. The decrease in diet overlap between the lynx (specialist) and the badger resulted from the large reduction in rabbit consumption by badgers. The reduced diet overlap between the mongoose and the lynx resulted from the diversification of mongoose diet after RHD.

\section{Behavioural responses of the Iberian lynx}

The increase in home range size of adult lynx females tends to fulfil their energetic demands with a depleted staple prey (Aldama 1993). Decreases of home range sizes with prey decreases have been previously reported for the Iberian lynx (Palomares 2001), and for L. canadensis (Ward \& Krebs 1985) and L. rufus (Knick 1990). However, in these cases, and in contrast to our results, males also increased their home ranges. Iberian lynx reproduction was also inhibited as a consequence of prey decline, as described in other lynx species (Brand \& Keith 1979; Knick 1990; O’Donoghue et al. 1997). The social system of the Iberian lynx seemed to have been disrupted during the first year of the rabbit reduction, as indicated by the lack of dispersal and the increased local density. A similar breakdown of the social system has been described for the Canada lynx at the low phase of hares (Poole 1995).

\section{Numerical responses}

The number of carnivore tracks encountered along transects is a function of activity as well as population size (Edwards, de Preu, Schakeshaft, \& Crealy 2000). In our case, an increase of carnivore movements in search of alternative prey could be expected after the rabbit decline. Under these circumstances, track-based population indices may remain static or even increase despite a population decline (Allen, Engeman, \& Krupa 1996). Consequently, the red fox track index decline can be confidently attributed to a reduction in its actual abundance. In the case of the remaining carnivores, a population decrease must not be discarded, as it could be masked by an increase of individual movements.

Pech and Hood (1998) predicted declines in foxes as rabbits decreased with the increasing impact of RHD in 
Australia. However, Edwards, Dobbie, and Berman (2002) did not detect any red fox population reduction in the wake of RHD in central Australia. The downward trend in fox abundance index in our study could be related to the replacement of rabbits with less energetically profitable prey (see Table 2), which could have affected foxes' reproductive output. Fox litter size in Doñana after the arrival of RHD (Zapata, Travaini, \& Delibes 1998) was among the lowest ever reported (Gortázar, Ferreras, Villafuerte, Martin, \& Blanco 2003). Such link between diet changes and reduced productivity was reported in north-eastern Spain (Villafuerte et al. 1996).

There are several explanations for the apparent lack of numerical responses to the rabbit decline in most Doñana carnivores. First, the records of carnivore abundance indices based on tracks begin in the autumn following the RHD outbreak, and therefore they would have missed any shortterm numerical response after the rabbit crash (spring 1990). Second, the size of the rabbit decline in our study is far smaller than the changes in numbers of prey in northern latitudes (Brand \& Keith 1979; Korpimäki 1993). Therefore, we should expect numerical responses of predators from Doñana smaller than those reported for predators in northern latitudes.

Although track transects revealed no clear trend in the Iberian lynx following the rabbit crash, a regional decline in the whole Doñana area $\left(1600 \mathrm{~km}^{2}\right)$ occurred between 1992 and 1999 (Ferreras, Gaona, Palomares, \& Delibes 2001), likely related to the overall rabbit decline. Similarly, numerical responses of specialist predators such as the Canada lynx to declines in their prey are usually delayed (O'Donoghue et al. 1997).

\section{Predation and the lack of rabbit recovery after RHD}

Most rabbit populations along the Iberian Peninsula have not recovered after the RHD outbreak (Delibes-Mateos et al. 2009). The causes could be multiple and differ among rabbit populations (Calvete 2006; Williams et al. 2007). Some studies have suggested that predation might hamper rabbit population recovery after a large decrease caused by factors other than predation (Trout \& Tittensor 1989; Marchandeau, Chaval, \& Le Goff 2000; Reddiex, Hickling, Norbury, \& Frampton 2002). Rabbit populations could have entered into a low-density equilibrium, regulated by predation ('predator pit', Banks 2000), with the joint effect of the diverse predator community. This would represent a conservation conflict, since the rabbit scarcity can seriously threaten the persistence of specialist predators (Ferrer \& Negro 2004; Ferreras et al. 2010). Its rescue would require changes towards higher rabbit densities and some management measures should be undertaken, such as artificial increases of rabbit density by restocking or habitat improvements.

\section{Acknowledgements}

We thank R. Laffitte, J.M. Fedriani and J.J. Aldama for collecting field data. F. Palomares provided support with identification of prey remains and helpful suggestions on the manuscript, which were also provided by R. Villafuerte and S. Redpath. Financial support for the study was provided by the Spanish DGICYT Projects PB87-0405, PB90-1018, REN2001-0448/GLO, BOS2001-2391-C02-01, and Project CGL2009-10741 from Spanish Plan Nacional de I+ D and FEDER funds.

\section{References}

Aldama, J. J. (1993). Ecología energética y reproductiva del lince ibérico (Lynx pardina, Temminck 1824) en Doñana. PhD Dissertation. Complutense University of Madrid, Spain.

Allen, L., Engeman, R., \& Krupa, H. (1996). Evaluation of three relative abundance indices for assessing dingo populations. Wildlife Research, 23, 197-206.

Andersson, M., \& Erlinge, S. (1977). Influence of predation on rodent populations. Oikos, 29, 591-597.

Banks, P. B. (2000). Can foxes regulate rabbit populations? Journal of Wildlife Management, 64, 401-406.

Brand, C. J., \& Keith, I. B. (1979). Lynx demography during a snowshoe hare decline in Alberta. Journal of Wildlife Management, 43, 827-849.

Calvete, C. (2006). Modeling the effect of population dynamics on the impact of rabbit hemorrhagic disease. Conservation Biology, 20, 1232-1241.

Delibes, M. (1980). Feeding ecology of the Spanish Lynx in the Coto Doñana. Acta Theriologica, 25, 309-324.

Delibes-Mateos, M., de Simón, J. F., Villafuerte, R., \& Ferreras, P. (2008). Feeding responses of the red fox (Vulpes vulpes) to different wild rabbit (Oryctolagus cuniculus) densities: A regional approach. European Journal of Wildlife Research, 54, 71-78.

Delibes-Mateos, M., Delibes, M., Ferreras, P., \& Villafuerte, R. (2008). Key role of European rabbits in the conservation of the Western Mediterranean Basin Hotspot. Conservation Biology, 22, 1106-1117.

Delibes-Mateos, M., Ferreras, P., \& Villafuerte, R. (2009). European rabbit population trends and associated factors: A review of the situation in the Iberian Peninsula. Mammal Review, 39, 124-140.

Edwards, G. P., de Preu, N. D., Schakeshaft, B. J., \& Crealy, I. V. (2000). An avaluation of two methods of assessing feral cat and dingo abundance in central Australia. Wildlife Research, 27, 143-149.

Edwards, G. P., Dobbie, W., \& Berman, D. M. (2002). Population trends in European rabbits and other wildlife of central Australia in the wake of rabbit haemorrhagic disease. Wildlife Research, 29, 557-565.

Fernández, C. (1993). Effect of the viral haemorrhagic pneumonia of the wild rabbit on the diet and breeding success of the golden eagle Aquila chrysaëtos (L.). Revue d'Ecologie-La Terre et la Vie, 48, 323-329.

Ferrer, M., \& Negro, J. J. (2004). The near extinction of two large European predators: Super specialists pay a price. Conservation Biology, 18, 344-349. 
Ferreras, P. (1994). Patrones de dispersión del lince ibérico (Lynx pardina) en Doñana e implicaciones para su conservación. (p. 278). PhD Dissertation. Autónoma University of Madrid, Spain.

Ferreras, P., Beltrán, J. F., Aldama, J. J., \& Delibes, M. (1997). Spatial organization and land tenure system of the endangered Iberian lynx (Lynx pardinus). Journal of Zoology, London, 243, 163-189.

Ferreras, P., Delibes, M., Palomares, F., Fedriani, J. M., Calzada, J., \& Revilla, E. (2004). Proximate and ultimate causes of dispersal in the Iberian lynx Lynx pardinus. Behavioral Ecology, 15, 31-40.

Ferreras, P., Gaona, P., Palomares, F., \& Delibes, M. (2001). Restore habitat or reduce mortality? Implications from a population viability analysis of the Iberian lynx. Animal Conservation, 4, 265-274.

Ferreras, P., Rodríguez, A., Palomares, F., \& Delibes, M. (2010). Iberian lynx: The uncertain future of a critically endangered cat. In D. W. Macdonald, \& A. J. Loveridge (Eds.), Biology and conservation of wild felids (pp. 507-520). Oxford: Oxford University Press.

Fuller, T. K. (1989). Population dynamics of wolves in north-central Minnesota. Wildlife Monographs, 105, 1-41.

Futuyma, D. J., \& Moreno, G. (1988). The evolution of ecological specialization. Annual Review of Ecology and Systematics, 19, 207-233.

Gil-Sánchez, J. M., Ballesteros-Duperón, E., \& Bueno-Segura, J. F. (2006). Feeding ecology of the Iberian lynx Lynx pardinus in eastern Sierra Morena (Southern Spain). Acta Theriologica, 51, 85-90.

Gortázar, C., Ferreras, P., Villafuerte, R., Martin, M., \& Blanco, J. C. (2003). Habitat related differences in age structure and reproductive parameters of red foxes. Acta Theriologica, 48, 93-100.

Kenward, R. E., \& Hodder, K. H. (1996). Ranges V. An analysis system for biological location data. Wareham: Institute of Terrestrial Ecology.

Knick, S. T. (1990). Ecology of Bobcats relative to exploitation and a prey decline in Southeastern Idaho. Wildlife Monographs, 108, $1-42$.

Korpimäki, E. (1993). Regulation of multiannual vole cycles by density-dependent avian and mammalian predation? Oikos, 66, 359-363.

Levins, R. (1968). Evolution in changing environments. Princeton, NJ: Princeton University Press.

Lockie, J. D. (1959). The estimation of the food of foxes. Journal of Wildlife Management, 23, 224-227.

Marchandeau, S., Chaval, Y., \& Le Goff, E. (2000). Prolonged decline in the abundance of wild European rabbits Oryctolagus cuniculus and high immunitiy level over three years following the arrival of rabbit haemorrhagic disease. Wildlife Biology, 6, 141-147.

Martín, R., Rodríguez, A., \& Delibes, M. (1995). Local feeding specialization by badgers (Meles meles) in a mediterranean environment. Oecologia, 101, 45-50.

Martínez, J. A., \& Zuberogoitia, I. (2001). The response of the Eagle Owl (Bubo bubo) to an outbreak of the rabbit haemorrhagic disease. Journal für Ornithologie, 142, 204-211.

Mclellan, B. N. (1988). Dynamics of a grizzly bear population during a period of industrial resource extraction. I. Density and age-sex composition. Canadian Journal of Zoology, 67, 1856-1860.
Moreno, S., Beltrán, J. F., Cotilla, I., Kuffner, B., Laffite, R., Jordán, G., et al. (2007). Long-term decline of the European wild rabbit (Oryctolagus cuniculus) in south-western Spain. Wildlife Research, 34, 652-658.

Newton, I. (1998). Predation. In I. Newton (Ed.), Population limitation in birds (pp. 211-248). San Diego, USA: Academic Press.

O’Donoghue, M., Boutin, S., Krebs, C. J., \& Hofer, E. J. (1997). Numerical responses of coyotes and lynx to the snowshoe hare cycle. Oikos, 80, 150-162.

O’Donoghue, M., Boutin, S., Krebs, C. J., Murray, D. L., \& Hofer, E. J. (1998). Behavioural responses of coyotes and lynx to the snowshoe hare cycle. Oikos, 82, 169-183.

Palomares, F. (1993). Opportunistic feeding of the Egyptian mongoose, Herpestes ichneumon (L.) in Southwestern Spain. Revue d'Ecologie-La Terre et la Vie, 48, 295-304.

Palomares, F. (2001). Vegetation structure and prey abundance requirements of the Iberian lynx: Implications for the design of reserves and corridors. Journal of Applied Ecology, 38, 9-18.

Palomares, F., \& Delibes, M. (1990). Factores de transformación para el cálculo de la biomasa consumida por Gineta (Genetta genetta) y meloncillo (Herpestes ichneumon) (Carnivora, Mammalia). Miscelànea Zoologica, 14, 233-236.

Palomares, F., \& Delibes, M. (1991). Alimentación del meloncillo Herpestes ichneumon y de la gineta Genetta genetta en la Reserva Biológica de Doñana, S.O. de la península Ibérica. Doñana, Acta Vertebrata, 18, 5-20.

Palomares, F., \& Delibes, M. (1992). Some physical and population characteristics of Egyptian mongooses (Herpestes ichneumon L., 1758) in Southwestern Spain. Zeitschrift für Säugetierkunde, 57, 94-99.

Palomares, F., \& Delibes, M. (1994). Spatio-temporal ecology and behavior of European genets in Southwestern Spain. Journal of Mammalogy, 75, 714-724.

Palomares, F., Delibes, M., Revilla, E., Calzada, J., \& Fedriani, J. M. (2001). Spatial ecology of Iberian lynx and abundance of European rabbits in southwestern Spain. Wildlife Monographs, 148, 1-36.

Pech, R. P., \& Hood, G. R. (1998). Foxes, rabbits, alternative prey and rabbit calicivirus disease: Consequences of a new biological control agent for an outbreaking species in Australia. Journal of Applied Ecology, 35, 434-453.

Pianka, E. R. (1973). The structure of lizard communities. Annual Review of Ecology and Systematics, 4, 53-74.

Poole, K. G. (1995). Spatial organization of a lynx population. Canadian Journal of Zoology, 73, 632-641.

Rau, J. (1987). Ecología del zorro, Vulpes vulpes L., en la Reserva Biológica de Doñana, S.O. de España. (p. 265). PhD Dissertation. Sevilla University, Spain.

Reddiex, B., Hickling, G. J., Norbury, G. L., \& Frampton, C. M. (2002). Effects of predation and rabbit haemorrhagic disease on population dynamics of rabbits (Oryctolagus cuniculus) in North Canterbury, New Zealand. Wildlife Research, 29, 627-633.

Revilla, E., Delibes, M., \& Travaini, A. (1999). Physical and population parameters of Eurasian badgers (Meles meles L.) from Mediterranean Spain. Zeitschrift für Säugetierkunde, 64, 269-276.

Revilla, E., \& Palomares, F. (2002). Does local feeding specialization exist in Eurasian badgers? Canadian Journal of Zoology, 80, 83-93.

SPSS-Inc. (2002). SPSS for windows v 11.5.1. Chicago, IL: SPSSInc. 
Tablado, Z., Tella, J. L., Sánchez-Zapata, J. A., \& Hiraldo, F. (2010). The paradox of the long-term positive effects of a North American crayfish on a European community of predators. Conservation Biology, 24, 1230-1238.

Trout, R. C., \& Tittensor, A. M. (1989). Can predators regulate wild rabbit Oryctolagus cuniculus population density in England and Wales? Mammal Review, 19, 153-173.

Villafuerte, R., Calvete, C., Blanco, J. C., \& Lucientes, J. (1995). Incidence of viral hemorrhagic disease in wild rabbit populations in Spain. Mammalia, 59, 651-659.

Villafuerte, R., Calvete, C., Gortázar, C., \& Moreno, S. (1994). First epizootic of rabbit hemorrhagic disease in free living populations of Oryctolagus cuniculus at Doñana National Park, Spain. Journal of Wildlife Diseases, 30, 176-179.

Villafuerte, R., Luco, D. F., Gortázar, C., \& Blanco, J. C. (1996). Effect on red fox litter size and diet after rabbit haemorrhagic disease in northeastern Spain. Journal of Zoology, London, 240, 764-767.

Virgós, E., Llorente, M., \& Cortes, Y. (1999). Geographical variation in genet (Genetta genetta L.) diet: A literature review. Mammal Review, 29, 117-126.

Ward, R. M. P., \& Krebs, C. J. (1985). Behavioral responses of lynx to declining snowshoe hare abundance. Canadian Journal of Zoology, 63, 2817-2824.

Williams, D., Acevedo, P., Gortázar, C., Escudero, M., Labarta, J., Marco, J., et al. (2007). Hunting for answers: Rabbit (Oryctolagus cuniculus) population trends in northeastern Spain. European Journal of Wildlife Research, 53, 1928.

Zapata, S. C., Travaini, A., \& Delibes, M. (1998). Reproduction of the red fox, Vulpes vulpes, in Doñana, southern Spain. Mammalia, 62, 139-142.

Available online at www.sciencedirect.com 